\title{
Prevalence and Aetiology of Dental Trauma in 8-14year old school-going children of Hyderabad city, India
}

\begin{abstract}
Aims and Objectives: To determine the prevalence and etiology of fractured anterior teeth due to trauma among 8-14 years old school going children of Hyderabad city.

Materials and method: A cross-sectional study was carried out in 8-14 year old children studying in various schools of Hyderabad for the assessment of traumatic injuries of anterior teeth. Clinical examination was carried out and type of teeth affected, type of fracture, overjet and lip competence were noted. A closed end questionnaire was given to children with questions regarding etiology of trauma, place of injury, symptoms or outcomes after the injury, whether a dentist was consulted, type of treatment done by dentist and time elapsed between trauma and treatment. All the results were analyzed using "statistical package for social sciences" (SPSS) 20.0 software.

Results: The prevalence of dental trauma was found to be 7.84\%. 11-14year old children showed higher prevalence. Males were more affected than females. Maxillary central incisors were most affected. Fracture involving enamel and dentin were recorded the highest. Children having overjet of $>3 \mathrm{~mm}$ and incompetent lips were at a higher risk of dental trauma ( $\mathrm{p}$ value $=0.001$ ). The most common cause of injury was sports and home was the most common place of occurrence of injury. Most of the traumatic dental injuries (TDI) did not undergo any treatment.

Conclusion: Increasing the awareness of the parents and teachers about the prevention of TDI and the importance of consulting the dentist after trauma should be instituted.
\end{abstract}

Keywords: Dental trauma, school-going children, Hyderabad

\section{Introduction:}

Dental trauma (traumatic dental injury) is usually sudden, circumstantial, unexpected, and accidental and often requires emergency attention. It is not a disease but a consequence of several unavoidable risk factors in life.[1] The prognosis of treatment of dental trauma is dependent on the time elapsed between the time of injury and treatment. This highlights the importance of first aid and the need to educate the public. Trauma to the anterior teeth poses a tremendous challenge to the dental profession in the treatment approach and hence the focus shifted towards prevention of traumatic injuries at a community level. The appearance and position of the anterior teeth have important psychological and social impacts on the children's quality of life. When injuries to incisor(s) produce pain, disfigurement, poor esthetics, or other psychological effects, children may avoid laughing or smiling, and this can

\begin{tabular}{|l|l|}
\hline \multicolumn{2}{|c|}{ Access this article online } \\
\hline \multirow{2}{*}{$\begin{array}{l}\text { Website: } \\
\text { www.ujds.in }\end{array}$} & Quick Response Code \\
\hline $\begin{array}{l}\text { DOI: } \\
\text { https://doi.org/10.21276/ujds.2020.6.3.14 }\end{array}$ & \\
\hline
\end{tabular}

affect their social relationships. In developing countries like India where the incidence of dental caries is declining, dental trauma has become a major oral health issue among children and adolescents. The prevalence of dental trauma has been found to differ considerably in various epidemiological

\author{
${ }^{1}$ AHMED, T., ${ }^{2}$ KAUSHAL, N., ${ }^{3}$ SINGH, S., ${ }^{4}$ AGARWAL, R. \\ ${ }^{1}$ Department of Pedodontics and Preventive Dentistry, \\ Army College of Dental Sciences, Secunderabad \\ ${ }^{2}$ Department of Oral and Maxillofacial Surgery, Army \\ College of Dental Sciences, Secunderabad \\ ${ }^{3}$ Consultant Oral and Maxillofacial Surgeon, Leela Devi \\ Medical Centre, Lucknow \\ ${ }^{4}$ Department of Oral and Maxillofacial Surgery, Babu \\ Banarasi Das College of Dental Sciences, Lucknow \\ Address for Corresponding : Dr. Tanzeem Ahmed \\ Department of Pedodontics and Preventive Dentistry \\ Army College of Dental Sciences \\ Secunderabad, Telangana - 500087 \\ Email : tanzeemsahmed@gmail.com
}

Received : 26 August 2020, Published : 31 Dec. 2020

How to cite this article: Ahmed, T., Kaushal, N., Singh, S., \& Agarwal, R. (2021). Prevalence and aetiology of dental trauma in 8-14 year old school-going children of Hyderabad city, India. UNIVERSITY JOURNAL OF DENTAL SCIENCES, 6(3).32-38 
studies. The great variation might be due to a number of factors such as the criteria used for classification, status of dentition, geographical, and behavioral differences between locations and countries.[2-4] The present study was carried out to determine the prevalence and etiology of fractured anterior teeth and its relation with predisposing risk factors among 8-14 years old school going children of Hyderabad.

\section{Materials and Method:}

A cross-sectional study was carried out in age group of 8-14 year old children who were studying in various schools of Hyderabad for the assessment of traumatic injuries of anterior teeth. Ethical clearance was obtained from the ethical committee. The permission to examine the children was taken from the respective of head of the institutions of selected schools in Hyderabad. A sample of 2104 school going children was selected using the random sampling technique. The inclusion criteria were cooperative school going children aged between 8-14 years with erupted permanent incisors. Exclusion criteria were children with any communicable or systemic disease or special child. Root fractures were not included as radiographs were not taken. Loss of teeth other than traumatic injuries, teeth with developmental defects and children undergoing orthodontic therapy were also excluded from the study. Trained clinician examined children under natural daylight with sterile mouth mirrors and probes for traumatic dental injuries of anterior permanent teeth following modified version of Ellis and Davey classification (Table 1). The findings were noted which included demographic data, teeth affected, type of fracture, overjet, lip competence and number of teeth affected. Lip competence was categorized as competent and incompetent.Lip competency was recorded when lips were in contact without strain at rest position of mandible. Inter-labial distance at the rest position more than $3-4 \mathrm{~mm}$ was considered as lip incompetency. Measurement of maxillary overjet was made with the teeth in centric occlusion; the distance from the labioincisal edge of the most prominent maxillary incisor to labial surface of the corresponding mandibular incisor was measured using a Community Periodontal Index of Treatment Needs (CPITN) probe, as described in the 1997WHO basic oral health survey guidelines. Overjet findings were grouped into 2 categories: $<3 \mathrm{~mm}$ and $>3 \mathrm{~mm}$.

A closed end questionnaire was given to children with questions regarding etiology of trauma, place of injury, symptoms or outcomes after the injury, whether a dentist was consulted, type of treatment done by dentist and time elapsed between trauma and treatment. The questionnaire was explained to the children and was then collected from them after they answered the questionnaire. All the results were analyzed using "statistical package for social sciences" (SPSS) 20.0 software.

Table 1: The types of trauma included in the study according to the modified Ellis classification and criteria for traumatic dental injuries [15]

\begin{tabular}{|c|c|c|}
\hline CODE $^{*}$ & CRITERIA & DESCRIPTION \\
\hline 0 & No trauma & $\begin{array}{c}\text { Simple fracture of crown, enamel only; } \\
\text { involving little or no dentin }\end{array}$ \\
\hline 1 & Enamel fracture & $\begin{array}{c}\text { Extensive fracture of crown involving } \\
\text { considerable dentin but with no pulp }\end{array}$ \\
\hline 2 & Enamel and dentin fracture & $\begin{array}{c}\text { Extensive fracture of the crown } \\
\text { involving considerable dentin and } \\
\text { exposing dental pulp }\end{array}$ \\
\hline 3 & Enamel and dentin fracture with pulp \\
\hline 4 & Non-vital tooth with discoloration & $\begin{array}{c}\text { Traumatized tooth that is non-vital and } \\
\text { is discoloured with or without loss of } \\
\text { crown structure }\end{array}$ \\
\hline 6 & Total tooth loss & $\begin{array}{c}\text { Absence of tooth due to complete ex- } \\
\text { articulation }\end{array}$ \\
\hline
\end{tabular}

*Injuries other than these were excluded from the study

\section{Results:}

The prevalence of dental trauma was found to be $7.84 \%$ $(n=165)$ of the total sample size $(n=2104)$ examined. The number of teeth traumatized was 269 . Out of them more number of traumatized teeth was found in 11-14 year age group (77.6\%) as compared to 8-10 year age group (22.3\%). $190(70.6 \%)$ belonged to males who suffered from dental trauma and $79(29.4 \%)$ belonged to females. Maxillary central incisors were the most commonly affected teeth by trauma, followed by maxillary lateral incisors, mandibular central incisors and least affected teeth were mandibular lateral incisors. $33.5 \%$ teeth that were traumatized belonged to right maxillary central incisors, $38.7 \%$ teeth were left maxillary central incisors, $4.5 \%$ of affected teeth were maxillary right lateral incisor, $7.1 \%$ teeth were maxillary left lateral incisors, $2.6 \%$ teeth were mandibular left central incisors, $7.1 \%$ teeth were mandibular right central incisors, $2.6 \%$ teeth were mandibular left lateral incisors and $4.1 \%$ teeth were mandibular right lateral incisors. Fracture involving enamel and dentin were recorded the highest $(46.1 \%)$ followed by enamel fracture $(43.9 \%)$; fracture involving enamel, dentin and pulp (6.7\%), discolored teeth $(2.6 \%)$ and avulsion $(0.7 \%)$. The majority of teeth which were traumatized $(54.6 \%)$ belonged to children having overjet more than $3.0 \mathrm{~mm} .32 .2 \%$ of traumatized teeth belonged to 
children with incompetent lips (Table 2). The most frequent cause of injury observed was due to sports $(27.5 \%)$, followed by misuse of teeth $(23.0 \%)$; due to falls $(19.3 \%)$, collision with objects or people $(11.9 \%)$; traffic accidents $(10.0 \%)$ and fight $(8.2 \%)$. The place of occurrence of most of the teeth fracture was at home (53.2\%) followed by outside home or school (24.2\%) and school (22.7\%). Following dental trauma, 104 out of 269 traumatized teeth $(38.7 \%)$ reported with pain, 66 teeth $(24.5 \%)$ reported with sensitivity, 28 teeth $(10.4 \%)$ reported with swelling and 4 teeth $(1.5 \%)$ reported with discoloration. 67 teeth which were traumatized (24.9\%) were asymptomatic. Immediately after trauma only $43.5 \%$ reported to dentist. Only $11.9 \%$ of the traumatized teeth were seen by the dentist on the same day of trauma. Majority of teeth affected by dental trauma $(55.8 \%)$ were devoid of any treatment (Table 3 ). The etiological factors for dental trauma were different for different age groups. Among the 8-10 year old age group the most common etiology for dental trauma was fall followed by sports injury, collision, teeth misuse, fight and traffic accident. Among 11-14 year old age group the most common etiology of dental trauma was teeth misuse followed by sports injury, fall, traffic accident, collision and fight. The association of etiological factors of dental trauma with age of children was found to be statistically significant. The major cause of dental trauma differed in males and in females. Sports were the major etiology behind dental trauma $(29.5 \%)$ in males whereas in females the major etiology behind dental trauma was teeth misuse $(26.6 \%)$ followed by fall $(24.1 \%)$. The association between the cause of dental trauma and gender was found to be statistically nonsignificant (Table 4). The association of dental trauma with overjet $>3 \mathrm{~mm}$ and incompetent lips was found to be statistically significant $(\mathrm{p}$ value $=0.001)$. Children with more than $3 \mathrm{~mm}$ overjet were 6.446 times at a higher risk of dental trauma as compared to children with less than $3 \mathrm{~mm}$ overjet and children with incompetent lips were 4.136 times at a higher risk of dental trauma as compared to children with competent lips (Table 5).

Table 2: Demographic and clinical characteristics of teeth affected by dental trauma

Table 3: Distribution of details of traumatic injuries

\begin{tabular}{|c|c|c|c|c|c|c|}
\hline $\begin{array}{l}\text { Age of affected } \\
\text { children }\end{array}$ & $\begin{array}{c}\text { Number of } \\
\text { affected } \\
\text { children }\end{array}$ & \multicolumn{2}{|c|}{ Percentage \% } & $\begin{array}{l}\text { Gender of } \\
\text { affected } \\
\text { children }\end{array}$ & $\begin{array}{c}\text { Number of } \\
\text { affected } \\
\text { children }\end{array}$ & Percentage \% \\
\hline 8-10 years & 60 & \multicolumn{2}{|l|}{$22.3 \%$} & Male & 190 & $70.6 \%$ \\
\hline 11-14 years & 209 & \multicolumn{2}{|c|}{$77.6 \%$} & Female & 79 & $29.4 \%$ \\
\hline \multicolumn{7}{|c|}{ Distribution of traumatic dental injury according to type of teeth affected } \\
\hline Maxillary Arch & $\begin{array}{l}\text { Number of teeth } \\
\text { affected }\end{array}$ & \multicolumn{2}{|c|}{ Percentage \% } & $\begin{array}{l}\text { Mandibular } \\
\text { Arch }\end{array}$ & \begin{tabular}{|l|l|}
$\begin{array}{l}\text { Number of } \\
\text { teeth } \\
\text { affected }\end{array}$ \\
\end{tabular} & Percentage $\%$ \\
\hline $\begin{array}{l}\text { Right central } \\
\text { incisor }\end{array}$ & 90 & \multicolumn{2}{|l|}{$33.5 \%$} & $\begin{array}{l}\text { Left central } \\
\text { incisor }\end{array}$ & 7 & $2.6 \%$ \\
\hline $\begin{array}{l}\text { Right lateral } \\
\text { incisor }\end{array}$ & 12 & \multicolumn{2}{|l|}{$4.5 \%$} & $\begin{array}{l}\text { Left lateral } \\
\text { incisor }\end{array}$ & 7 & $2.6 \%$ \\
\hline $\begin{array}{l}\text { Left central } \\
\text { incisor }\end{array}$ & 104 & \multicolumn{2}{|l|}{$38.7 \%$} & $\begin{array}{l}\text { Right central } \\
\text { incisor }\end{array}$ & 19 & $7.1 \%$ \\
\hline $\begin{array}{l}\text { Left lateral } \\
\text { incisor }\end{array}$ & 19 & \multicolumn{2}{|l|}{$7.1 \%$} & $\begin{array}{l}\text { Right lateral } \\
\text { incisor }\end{array}$ & 11 & $4.1 \%$ \\
\hline \multicolumn{7}{|c|}{ Distribution of traumatic dental injury according to the type of tooth fracture } \\
\hline \multicolumn{2}{|c|}{ Type of fracture } & \multicolumn{3}{|c|}{ Number of teeth affected } & \multicolumn{2}{|c|}{ Percentage $\%$} \\
\hline \multicolumn{2}{|c|}{ Enamel fracture } & \multicolumn{3}{|c|}{118} & \multicolumn{2}{|c|}{$43.9 \%$} \\
\hline \multicolumn{2}{|c|}{ Enamel and dentin fracture } & \multicolumn{3}{|l|}{124} & \multicolumn{2}{|l|}{$46.1 \%$} \\
\hline \multicolumn{2}{|c|}{$\begin{array}{l}\text { Enamel and dentin fracture with } \\
\text { pulp exposure }\end{array}$} & \multicolumn{3}{|l|}{18} & \multicolumn{2}{|l|}{$6.7 \%$} \\
\hline \multicolumn{2}{|c|}{ Non vital tooth with discoloration } & \multicolumn{3}{|l|}{7} & \multicolumn{2}{|l|}{$2.6 \%$} \\
\hline \multicolumn{2}{|c|}{ Tooth loss (Aulsion) } & \multicolumn{3}{|l|}{2} & \multicolumn{2}{|l|}{$0.7 \%$} \\
\hline Distribution of & caumatic dental in & ury according & & et of teeth and & d lip competenc & n traumatized \\
\hline Overjet & $\begin{array}{l}\text { Number of } \\
\text { affected teeth }\end{array}$ & $\begin{array}{l}\text { Percentage } \\
\%\end{array}$ & & ompetence & $\begin{array}{l}\text { Number of } \\
\text { affected teeth }\end{array}$ & Percentage $\%$ \\
\hline$<3 \mathrm{~mm}$ & 122 & $45.4 \%$ & & eetent & 181 & $67.3 \%$ \\
\hline$>3 \mathrm{~mm}$ & 147 & $54.6 \%$ & & npetent & 88 & $32.3 \%$ \\
\hline
\end{tabular}


University J Dent Scie 2020; Vol. 6, Issue 3

Table 4: Association Of Etiological Factors With Age and Gender

\begin{tabular}{|c|c|c|c|c|c|}
\hline \multicolumn{6}{|c|}{ Distribution of traumatic dental injuries according to the causes of injury and place of trauma } \\
\hline Cause of injury & $\begin{array}{l}\text { No. of teeth } \\
\text { affected }\end{array}$ & Percentage $\%$ & Place of injury & \begin{tabular}{|l|}
$\begin{array}{l}\text { No. of teeth } \\
\text { affected }\end{array}$ \\
\end{tabular} & Percentage $\%$ \\
\hline Fall & 52 & $19.3 \%$ & Home & 143 & $53.2 \%$ \\
\hline Sport & 74 & $27.5 \%$ & School & 61 & $22.7 \%$ \\
\hline $\begin{array}{l}\text { Collision with object } \\
\text { or person }\end{array}$ & 32 & $11.9 \%$ & Outside & 65 & $24.2 \%$ \\
\hline Traffic accident & 27 & $10.0 \%$ & $\begin{array}{l}\text { Missing } \\
\text { information }\end{array}$ & 00 & 00 \\
\hline Fight/ violence & 22 & $8.2 \%$ & & & \\
\hline Teeth misuse & 62 & $23.0 \%$ & & & \\
\hline \multicolumn{6}{|c|}{$\begin{array}{c}\text { Distribution of traumatic dental injuries according to the symptoms after injury and whether a } \\
\text { dentist/doctor was consulted }\end{array}$} \\
\hline $\begin{array}{l}\text { Symptoms after } \\
\text { injury }\end{array}$ & $\begin{array}{l}\text { Number of } \\
\text { teeth } \\
\text { affected }\end{array}$ & Percentage $\%$ & \begin{tabular}{|l|} 
Immediate \\
consultation \\
for treatment
\end{tabular} & \begin{tabular}{|l|l|}
$\begin{array}{l}\text { Number of } \\
\text { teeth }\end{array}$ \\
\end{tabular} & Percentage $\%$ \\
\hline Pain & 104 & $38.7 \%$ & Doctor & 3 & $1.1 \%$ \\
\hline Swelling & 28 & $10.4 \%$ & Dentist & 117 & $43.5 \%$ \\
\hline Sensitivity & 66 & $24.5 \%$ & None & 149 & $55.4 \%$ \\
\hline Discoloration & 4 & $1.5 \%$ & & & \\
\hline Nothing happened & 67 & $24.9 \%$ & & & \\
\hline \multicolumn{6}{|c|}{$\begin{array}{c}\text { Distribution of traumatic dental injuries according to time elapsed between trauma and dental } \\
\text { treatment }\end{array}$} \\
\hline \multicolumn{4}{|c|}{\begin{tabular}{|l|l|} 
Time elapsed between trauma and dental treatment &
\end{tabular}} & $\begin{array}{l}\text { Number of } \\
\text { teeth }\end{array}$ & Percentage $\%$ \\
\hline \multicolumn{4}{|c|}{ On the day of accident } & 32 & $11.9 \%$ \\
\hline \multicolumn{4}{|c|}{1 to 7 days after accident } & 42 & $15.6 \%$ \\
\hline \multicolumn{4}{|c|}{8 days to 3 weeks after accident } & 1 & $0.4 \%$ \\
\hline \multicolumn{4}{|c|}{$\mathbf{1}^{\text {st }}$ month after accident } & 8 & $3.0 \%$ \\
\hline \multicolumn{4}{|c|}{3 months to 1 year after accident } & 16 & $5.9 \%$ \\
\hline \multicolumn{4}{|c|}{\begin{tabular}{|l|l} 
Sought for treatment when pain and discomfort occurred & \\
\end{tabular}} & 21 & $7.8 \%$ \\
\hline \multicolumn{6}{|c|}{ Distribution of traumatic dental injuries according to type of treatment done by dentist } \\
\hline \multicolumn{2}{|c|}{ Type of treatment } & \multicolumn{2}{|c|}{ Number of teeth } & \multicolumn{2}{|c|}{ Percentage \% } \\
\hline \multicolumn{2}{|l|}{ Medication given } & \multicolumn{2}{|c|}{63} & \multicolumn{2}{|c|}{$23.4 \%$} \\
\hline \multicolumn{2}{|l|}{ Other procedure } & 56 & & $20.8 \%$ & \\
\hline
\end{tabular}

\begin{tabular}{|c|c|c|c|c|c|c|c|c|}
\hline \multirow{2}{*}{ Age } & \multicolumn{8}{|c|}{ Cause of injury } \\
\hline & Fall & Sport & Collision & Traffic accident & Fight & \multicolumn{2}{|c|}{ Teeth misuse } & Total \\
\hline 8-10yrs & 16 & 11 & 10 & 4 & 9 & \multicolumn{2}{|c|}{10} & 60 \\
\hline 11-14yrs & 36 & 63 & 22 & 23 & 13 & \multicolumn{2}{|l|}{52} & 209 \\
\hline \multicolumn{9}{|c|}{ Chi-square test $; *$ indicates significant at $\mathrm{p}=0.05$} \\
\hline \multicolumn{9}{|c|}{ Association Of Etiological Factors With Gender } \\
\hline \multirow[t]{2}{*}{ Gender } & \multicolumn{8}{|c|}{ Cause of injury } \\
\hline & Fall & Spor & Collisi & $\begin{array}{c}\text { Traffic } \\
\text { accident }\end{array}$ & Fight & $\begin{array}{l}\text { Teeth } \\
\text { misuse }\end{array}$ & & otal \\
\hline Male & $\begin{array}{c}33 \\
(17.4)\end{array}$ & $\begin{array}{c}56 \\
(29.5 \\
\end{array}$ & $25(13$. & $19(10.0)$ & $\begin{array}{c}16 \\
(8.4)\end{array}$ & 41 (21.6) & & $(100)$ \\
\hline Female & $\begin{array}{c}19 \\
(24.1)\end{array}$ & $\begin{array}{c}18 \\
(22.8\end{array}$ & $7(8.9$ & $8(10.1)$ & $\begin{array}{c}6 \\
(7.6)\end{array}$ & $21(26.6)$ & & (100) \\
\hline
\end{tabular}


University J Dent Scie 2020; Vol. 6, Issue 3

Table 5: Frequency Analysis And Logistic Regression Of The Association Between The Variables Studied And Dental Trauma In Children $(\mathrm{N}=2104)$

\begin{tabular}{|c|c|c|c|c|c|}
\hline Variable & \multicolumn{3}{|c|}{ Traumatic Injury n (\%) } & Odds ratio & $\mathrm{p}$ value \\
\hline Overjet & Yes & No & Total & \multicolumn{2}{|c|}{ OR $(95 \% \mathrm{CI})$ for overjet $(>3 \mathrm{~mm} /<3 \mathrm{~mm})$} \\
\hline$>3 \mathrm{~mm}$ & $\begin{array}{c}147 \\
(33.7)\end{array}$ & $\begin{array}{c}289 \\
(66.3) \\
\end{array}$ & 436 & \multirow[t]{2}{*}{$6.446(4.916-8.451)$} & \multirow[t]{2}{*}{$0.001^{*}$} \\
\hline$<3 \mathrm{~mm}$ & $\begin{array}{c}122 \\
(7.3)\end{array}$ & $\begin{array}{r}1546 \\
(92.7)\end{array}$ & 1668 & & \\
\hline $\begin{array}{c}\text { Lip } \\
\text { Competency }\end{array}$ & Yes & No & Total & \multicolumn{2}{|c|}{$\begin{array}{l}\text { OR (95\% CI) for Lip Competency } \\
\text { (Incompetent/Competent) }\end{array}$} \\
\hline Incompetent & $\begin{array}{c}88 \\
(31.3)\end{array}$ & $\begin{array}{c}193 \\
(68.7)\end{array}$ & 281 & \multirow[t]{2}{*}{$4.136(3.079-5.557)$} & \multirow[t]{2}{*}{$0.001^{*}$} \\
\hline Competent & $\begin{array}{c}181 \\
(9.9)\end{array}$ & $\begin{array}{c}1642 \\
(90.1)\end{array}$ & 1823 & & \\
\hline
\end{tabular}

Logistic Regression; OR - Odds Ratio, CI - Confidence Interval; * indicates significant at $\mathrm{p} \leq 0.05$

\section{Discussion:}

Prevention of TDIs will be possible only if it is based on reliable data on prevalence, cause and risk factors. Hence prevalence studies are considered to be basic tools for implementation of the effective educational strategies against fractures.[5] In the present study overall prevalence of TDIs to anterior teeth among school children aged 8-14 years in Hyderabad was found to be $7.84 \%$.This prevalence rate was found to be higher than found in the studies done by Singh N et al., Gupta S et al. and Nik-Hussein NN whereas, this rate was similar to those found in studies done by Govindarajan M et al. and Hegde R et al. Out of 269 teeth with TDIs, 190 were those of boys and 79 were those of girls with boys to girls ratio being 2.4:1 which showed that male predominance towards TDIs. This correlates with other studies done by Patel MC et al., Ravisankar TL et al., and Hegde et al. This could be attributed to the fact that boys engage in leisure activities or sports which are with a greater accidental risk than girls.[6-10]

In this study, peak age group to sustain TDIs was found to be 11-14 years in both boys and girls (77.6\%). This was in accordance with studies done by Ravisankar TL et al., and Hegde et al. Higher involvement of TDIs in the age group of 11-14 years could be explained on the basis of increased exposure to etiological and predisposing factors.[10-12] However, in the study conducted by Patel MC et al., highest prevalence of TDIs was found at the age of 9 years.[7] In the present study, maxillary central incisors are the most commonly affected teeth, followed by maxillary laterals.

Within the arch, the reason for increase in number of trauma to central incisor compared to lateral incisor can be explained by the fact that the central incisors are more proclined and forwardly placed than lateral incisors in the vertical plane. Since the mandible is not tightly connected to the cranial base, the force gets dissipated leading to relatively less trauma in the mandibular teeth. $[13,14]$ In the present study also it was found that maxillary teeth were more prone to injuries as compared to mandibular teeth. The most common type of injury found was enamel and dentin fracture $(32.87 \%)$ followed by crown fracture involving enamel $(59.80 \%)$ which was in accordance with earlier studies done by Naidoo $\mathrm{S}$ et al.[15] In contrast, studies done by Patel MC et al.[7], Ravisankar TL et al.[11], and Hegde et al.[10], found that enamel fracture was the most common injury. In this study about half the traumatic dental injuries have been associated with overjet of greater than $3 \mathrm{~mm}$. The reason could be that the increased overjet increases exposure of teeth which predisposes to trauma. Association between dental trauma and incompetent lips has been found to be statistically significant. The quality of lip coverage has an effect on severity of incisor trauma. In children with competent lips, when trauma occurs, the upper lip acts as cushion which absorbs some part of impact and distributes it over a broader surface. In case of children with incompetent lips, this protective function is absent which might explain the increase in the number of periodontal injuries.[16] It was found that the most common cause of traumatic injuries was sports and most common place of injury was home. Majority of injuries occur at home due to fact that children spend more time at home than at school and playground.[17] Therefore, preventive programs for the population studied, should be evolved to educate the parents and children primarily, and then the school authorities and sports coaches. In this study, majority of cases did not report for professional dental consultation after trauma showing that the patients usually wait until symptoms arise to seek dental treatment. Lack of adequate knowledge and proper 
motivation compounded by limitations imposed due to socioeconomic constraints could explain the high percentage of untreated injuries. There was lack of attitude and knowledge regarding the treatment of injured teeth.[7] This study has shown that dental awareness was very low as evident in number of children who were attended by the dentist.

In this study, only $11.9 \%$ visited dentist on same day of trauma had occurred. This explains the lack of awareness among the children and their parents regarding the time of dental visit after the traumatic episode despite the fact that time elapsed between the injury and treatment influences prognosis of tooth with TDIs.[17] Hence targeting the parents and school teachers through specific dental trauma prevention programs might be helpful. Furthermore, clear and simple informational campaigns through newspapers, television, brochures and posters are helpful strategies to raise the public awareness.[4] Identifying the etiological factors makes it possible to establish preventive measures aimed at avoiding future injuries. Adoption of safety measures and adequate supervision of children may help in preventing traumatic dental injuries. Early orthodontic treatment in children with predisposing factors to trauma such as a large overjet may be an effective preventive strategy.[13]

\section{Conclusion:}

Treatment received by the traumatized children seems to be insufficient compared to the high prevalence of dental trauma. This insufficiency may be due to lack of knowledge about the right emergency treatment at the right time by those dealing with the trauma cases or lack of facilities. There is a need to run educational programs to increase parents' awareness of the risk, distribution of educational brochures in schools and promoting the use of devices like mouth guards to protect the teeth and face from TDI. Raising the awareness of the public about this matter and the importance of consulting the dentist after trauma should be instituted at least using proper examination forms for recording the trauma cases in the school health services and the emergency and private dental clinics. Early orthodontic intervention might help in reducing the trauma incidence in children with excessive over jet and inadequate lip coverage. Improvement in the physical environment of children, utilization of preventive measures along with close supervision when they are involved in physical activities is likely to have a positive impact in reduction of TDI.

\section{References:}

1. Lam R. Epidemiology and outcomes of traumatic dental injuries: a review of the literature. Aust Dent J. 2016 Mar;61Suppl 1:4-20.

2. Petersson EE, Andersson L, Sorensen S. Traumatic oral vs non- oral injuries. An epidemiological study during one year in a Swedish country. Swed Dent J 1997; 21 (12):55-68.

3. Baldava $\mathrm{P}$, Anup N. Risk factors for traumatic dental injuries in an adolescent male population in India. Dent Traumatology 2008;24 (6):603-611 .

4. Amit V, Ravi K S, Roshan N M, Shashikiran N D. Analysis of reporting pattern in children aged 7-14years with traumatic injuries to permanent teeth. International Journal of Clinical Pediatric Dentistry Jan-Apr 2010; $3(1): 15-19$.

5. Schatz JP, Hakeberg M, Ostini E, Kiliaridis S. Prevalence of traumatic injuries to permanent dentition and its association with overjet in a Swiss child population. Dental Traumatology 2013;29 (2):110-114

6. Singh N, Singh A, Jolly MS. Prevalence of traumatic dental injuries in school going children of Lucknow, India. International Journal of Oral Health and Medical Research, July- august 2015;2 (2):39-42.

7. Patel MC, Sujan SG. The prevalence of traumatic dental injuries to permanent anterior teeth and its relation with predisposing risk factors among 8 to 13 years school children of Vadodara city: An epidemiological study. J Indian SocPedod Prey Dent 2012;30 (2): 151-157.

8. Nik-Hussein NN. Traumatic injuries to anterior teeth among school children in Malaysia. Dent Traumatol 2001; 17(4): 149-152.

9. Govindarajan M, Reddy VN, Ramalingam K, Durai KS, Arun P, Prabhu A. Prevalence of traumatic injuries to 
anterior teeth among three to thirteen year old school children of Tamilnadu. Contemporary clinical dentistry, Apr-Jun 2012; 3(2): 164-167.

10. Hegde R, Agrawal G. Prevalence of Traumatic Dental Injuries to the Permanent Anterior Teeth among 9- to 14-year-old Schoolchildren of Navi Mumbai (Kharghar-Belapur Region), India. Int J ClinPediatr Dent 2017;10(2):177-182.

11. Ravishankar TL, Kumar MA, Ramesh N, Chaitra TR. Prevalence of traumatic dental injuries to permanent incisors among 12 year old school children in Davangere, South India. The Chinese Journal of Dental Research 2010; 13(1): 57-60.

12. Bhat N, Agrawal A, Nagrajappa R, Roy SS, Singh KP, Chaudhary HV, Asawa K. Teeth fracture among visually impaired and sighted children of 12 and 15 years age groups of Udaipur city, India - A comparative study. Dental Traumatology 2011; 27(5):389-392.

13. Prasad S, Tandon S, Pahuja M, Wadhawan A. Prevalence of traumatic dental injuries in Farukhnagar, district Gurgaon. International Journal of scientific study, May 2014; 2(2): 44-49.

14. Batra M, Kandwal A, Gupta M, Tangade P, Dany SS, Rajput P. Prevalence of dental traumatic injuries to permanent incisors in Indian children: A cross-sectional survey. J Dent Sci Oral Rehab 2014; 5(1):1-4.

15. Naidoo S, Sheiham A, Tsakos G. Traumatic dental injuries of per $\neg$ manent incisors in 11- to 13 -year-old South African school children. Dent Traumatol 2009; 25(2): 224-8.

16. Garcia-Godoy F, Sanchez J R. Traumatic dental injuries in a sample of Dominican school children. Community Dent Oral Epidemiol, 1981: 9(4): 193-197.

17. Andreasen J, Andreasen FM. Textbook colour atlas of traumatic injuries to the teeth. 4th ed. Copenhagen: Munskgaard International Publishers; 2004: 912 pages. 